\title{
Nodular scleritis caused by neurosyphilis in an immunocompetent patient. Case report
}

\section{Escleritis nodular por neurosiffilis en paciente inmunocompetente. Reporte de caso}

\author{
José D. Paulo1,2*, Isabel C. Gómez-Suárez², and Diana C. Montoya-Carrasquilla²
}

${ }^{1}$ Ophthalmology department, Hospital Pablo Tobón Uribe, Universidad de Antioquia; Ophthalmology department, Universidad Pontificia Bolivariana. Medellín, Colombia

\begin{abstract}
Case report: A 59-year-old woman with nodular scleritis without improvement after oral treatment with non-steroidal anti-inflammatory drugs, and oral and topical corticosteroids. Tests were performed finding reactive VDRL in 32 dls and reactive FTA-ABS. A lumbar puncture evidenced pleocytosis. Nodular scleritis secondary to neurosyphilis was diagnosed and treatment with intravenous penicillin was initiated, showing improvement of scleral inflammation. Discussion: Scleritis due to syphilis is uncommon, and even more so if it is the only ocular manifestation. In addition, most reports of scleritis as a manifestation of syphilis have been described in people with HIV infection, but our patient was not immunocompromised, and HIV serology was negative.
\end{abstract}

Key words: Sclera. Syphilis. Scleral diseases. Uveitis. Ocular inflammation.

\section{Resumen}

Caso clínico: Mujer de 59 años con escleritis nodular en quien, al no tener respuesta al tratamiento con antiinflamatorios no esteroideos orales y corticoide oral y tópico, se ordenaron estudios paraclínicos que mostraron VDRL reactivo en 32 dls y FTA ABS en suero reactivo. Se realizó punción lumbar que evidenció pleocitosis. Con este resultado se diagnosticó escleritis nodular secundaria a neurosiffilis y se inició tratamiento con penicilina intravenosa, con lo cual se obtuvo mejoría del cuadro clínico. Discusión: El compromiso escleral por siffilis es poco común, y menos aún si es la única manifestación ocular; sumado a esto, la mayoría de los reportes de escleritis como manifestación de siffilis se han descrito en personas con infección por el VIH, a diferencia del presente caso, en el cual no hay inmunocompromiso y la serología para el VIH fue negativa.

Palabras clave: Esclera. Sífilis. Enfermedades de la esclera. Uveítis. Inflamación ocular. 


\section{Introduction}

Scleritis, which is the inflammation of the deep vascular plexus adjacent to the sclera, comprises a clinical picture characterized by a red eye with an appearance close to a purplish color due to the depth of the inflamed structures, edema that compromises the sclera and pain that increases with eye movements and palpation ${ }^{1}$. In 1976, Watson and Hayreh ${ }^{2}$ proposed a classification system that remains current to date: anterior scleritis is anatomically recognized as the inflammation that occurs anterior to the insertion of the rectus muscles, which in turn can be diffuse, nodular, necrotizing with signs of inflammation and necrotizing without signs of inflammation (scleromalacia perforans); the inflammation that occurs behind the insertion of the rectus muscles is known as posterior scleritis, which can be diffuse or nodular.

Unlike episcleritis, scleritis has been more frequently associated with systemic disorders. It is estimated that more than $50 \%$ of scleritis cases occur in the context of a systemic autoimmune disease, rheumatoid arthritis being the most prevalent, followed by seronegative spondyloarthropathies and vasculitis. The form of presentation of the inflammation plays an important role in the probability of association with systemic conditions; diffuse and nodular scleritis are less serious, and necrotizing scleritis is more serious, with or without signs of inflammation, where $80 \%$ of cases are associated with systemic diseases, mainly with granulomatosis with polyangiitis'.

Regarding infectious etiology, it occurs in $4-10 \%$ of patients with scleritis, and herpes zoster virus infection is the most common infectious cause.

In the context of trauma or eye surgery, the most common microorganism associated with postoperative infectious scleritis is Pseudomonas aeruginosa, responsible for $28-67 \%$ of cases $^{3}$. However, many other pathogens have been linked to scleral infections, including Borrelia burgdorferi, Mycobacterium tuberculosis, and Acanthamoeba. In isolated cases in immunocompromised patients with HIV infection, Treponema pallidum has been reported, always with associated systemic manifestations ${ }^{4,5}$.

We describe a case of atypical infectious scleritis.

\section{Clinical case}

A 59-year-old housewife with a history of arterial hypertension controlled with losartan. She has been managed for several years in the ophthalmology department for a diagnosis of moderate evaporative dry eye, with partial improvement with lubricating eye drops, and for hyperopia and presbyopia that improve with eyeglasses correction.

She consulted the general ophthalmology department due to one-month history of ocular pain in the left eye associated with red eye without changes in visual acuity, for which she was being treated with oral diclofenac with partial improvement of symptoms. Ocular examination revealed a corrected visual acuity of 20/20 in both eyes. The left eye showed a raised vascularized nodule of superior temporal location in the sclera, which did not blanch with phenylephrine. There were also conjunctival injection, cornea with lower punctate staining and a decreased tear breakup time. Intraocular pressure was $14 \mathrm{mmHg}$ in both eyes, the lens was clear, and the fundus did not reveal abnormal findings.

A diagnosis of anterior nodular scleritis (first episode) was made, initiating treatment with oral non-steroidal anti-inflammatory drugs and oral and topical corticosteroids, with no improvement after 2 weeks of treatment. Additionally, we ordered paraclinical studies (Table 1) that reported a reactive VDRL (Venereal Disease Research Laboratory) in 32 dls and FTA-ABS in reactive serum, so the patient was referred to clinical neurology, where they performed a lumbar puncture. VDRL in the cerebrospinal fluid (CSF) was negative, but pleocytosis was evidenced. With this result, the patient was admitted to the hospital with a diagnosis of nodular scleritis secondary to neurosyphilis for treatment with crystalline penicillin, 4,000,000 IU every 4 hours. One month after hospitalization, visual acuity was unchanged. The sclera showed no lesions. There was a clinical improvement of the inflammatory signs, and the rest of the eye examination was unchanged compared to the previous one. The CSF analysis 3 months after treatment revealed a total decrease in leukocyte, and serum VDRL titers were low (1:2 dls). The patient did not have other manifestations of neurosyphilis other than the inflammatory condition of the eye.

\section{Discussion}

Ocular involvement due to syphilis can occur in any of the stages, and iritis and chorioretinitis are the most frequent ocular forms; it is estimated to occur in $2.5-5 \%$ of patients who progress to the secondary and tertiary forms. A case series published by Barile and Flynn ${ }^{6}$ found that $4.3 \%$ of the patients with uveitis had ocular inflammation attributed to $T$. pallidum infection, and the 
Table 1. Laboratory tests performed when there was no evidence of scleritis improvement

\begin{tabular}{|c|c|}
\hline Paraclinical & Result (reference value) \\
\hline Chest x-ray & Mild bronchial changes \\
\hline PCR (mg/dl) & $5830(4500-11.000)$ \\
\hline 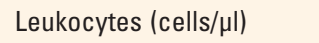 & $0.4(0-10)$ \\
\hline Neutrophils (\%) & $47.9(55-68)$ \\
\hline Lymphocytes (\%) & $41(23-38)$ \\
\hline Hemoglobin ( $g / d l)$ & $14.6(12-16)$ \\
\hline Hematocrit (\%) & $44.7(36-48)$ \\
\hline Rheumatoid factor (IU/ml) & $64(<60)$ \\
\hline ANA & Negative \\
\hline P-ANCA & Negative \\
\hline C-ANCA & Negative \\
\hline HIV (ELISA) & Negative \\
\hline HBAgs (IU/I) & $<0.10(<0.1-0.99)$ \\
\hline VDRL (serum) & Reactive 1:32 dls \\
\hline FTA - ABS (serum) & Positive \\
\hline CSF cytochemistry & $\begin{array}{l}\text { Clear appearance } \\
\text { Normal color } \\
\text { No bacteria } \\
\text { Leukocytes } 10 / \mathrm{mm}^{3}\left(0-5 / \mathrm{mm}^{3}\right) \\
\text { PMNN } 1 / \mathrm{mm}^{3}\left(0 / \mathrm{mm}^{3}\right) \\
\text { Mononuclear cells } 9 / \mathrm{mm}^{3}(0-5 / \\
\left.\mathrm{mm}^{3}\right) \\
\text { Red blood cells } 0 / \mathrm{mm}^{3}\left(0 / \mathrm{mm}^{3}\right) \\
\text { Proteins } 35.8 \mathrm{mg} / \mathrm{dl}(15-45 \mathrm{mg} / \mathrm{dl}) \\
\text { Glucose } 47 \mathrm{mg} / \mathrm{dl}(40-80 \mathrm{mg} / \mathrm{dl})\end{array}$ \\
\hline VDRL in CSF & Nonreactive \\
\hline
\end{tabular}

presentation was granulomatous iridocyclitis in $46 \%$, non-granulomatous iridocyclitis in $25 \%$, panuveitis in $13 \%$, posterior uveitis in $8 \%$, and keratouveitis in $8 \%$. Another more recent case series ${ }^{7}$ described the presentation of ocular syphilis in Korean patients without human immunodeficiency virus (HIV) coinfection, in which posterior uveitis was found in $38 \%$ of cases, panuveitis in $29 \%$ and optic neuritis in $11 \%$; there was involvement of anterior segment structures different from the iris only in two patients (4.4\%) in the form of interstitial keratitis, and there were no cases of scleritis or episcleritis.
Based on the above data, it can be concluded that scleral involvement due to syphilis is rare, and even less so if it is the only ocular manifestation. Additionally, most reports of scleritis as a manifestation of syphilis have been described in people with HIV infection, unlike this case, in which there was no immunocompromise and HIV serology was negative.

Fénolland, et al. ${ }^{8}$ described the case of a 47-year-old man with unilateral nodular anterior scleritis associated with non-granulomatous anterior uveitis, mild vitritis, and focal retinal vasculitis in the scleritis area. Syphilis and HIV serology was positive, neurosyphilis screening was negative, and the ocular inflammatory condition resolved with penicillin $\mathrm{G}$ treatment.

Similarly, in 2013, Lee, et al. ${ }^{5}$ reported the case of a 45-year-old man with a previous history of HIV infection who had a diffuse anterior scleritis associated with vitritis and hemorrhagic retinitis. The aqueous humor polymerase chain reaction was negative for viruses, while the RPR serology was positive. There was an improvement after 5 days of treatment.

Scleral involvement in people with HIV infection is independent of CD4 values and can even appear in the immune reconstitution stage, as reported by Moloney et al. ${ }^{4}$ in 2004 when describing a case of nodular scleritis in a patient with HIV whose previous CD4 titers were $12 \times 10^{9} \mathrm{cells} / \mathrm{l}$ and at the time of the ocular inflammatory condition, after 18 months of antiretroviral therapy, there were $340 \times 10^{9}$ cells/l, and also positive treponemal tests that in the study baseline were negative.

Regarding scleral or episcleral involvement due to syphilis in immunocompetent people, South Korea reported the case of a 62-year-old woman with recalcitrant episcleritis with a reactive VDRL test (1:32), pleocytosis in CSF $\left(10 / \mathrm{mm}^{3}\right)$ and reactive VDRL (1:2). The condition resolved in the first week of treatment ${ }^{9}$. This case is the most similar to our report and describes the association of scleritis due to syphilis with central nervous system involvement in an immunocompetent patient, suggesting that this etiology should be considered in all patients, since specific antibiotic treatment is decisive for improvement.

Neurosyphilis is difficult to diagnose because it does not have a characteristic pattern of presentation. In the absence of blood contamination in CSF, VDRL is highly specific, but its sensitivity ranges from $67-72 \%$, and a negative result does not rule it out. In our case, despite the negative VDRL result in the CSF, serum reactivity confirmed with a non-treponemal test (VDRL) and a treponemal test (FTA-ABS), added to the ocular 
involvement and the CSF pleocytosis, constitute neurosyphilis diagnostic criteria ${ }^{10,11}$.

Any form of ocular syphilis should be treated as neurosyphilis with crystalline penicillin in doses of 18-24 million IU per day for 10-14 days, intravenously, divided into six doses. Treatment with benzathine penicillin is not recommended because it does not reach therapeutic concentrations in the $\mathrm{CSF}^{11}$. Our patient was treated for neurosyphilis and showed improvement both clinically and by laboratory tests.

\section{Conclusion}

In all its stages, syphilis can cause variable ocular involvement, in most cases as posterior uveitis with or without optic neuritis; the involvement of anterior segment structures has been described in several reports as interstitial keratitis. Scleritis due to this cause is uncommon, clinical suspicion is required and this possibility should always be included in the diagnostic screening, recognizing that $T$. pallidum infection can be the cause of symptoms even in patients without HIV infection and without other ocular manifestations, and always rule out other infectious causes (the most common in scleritis are autoimmune). Once the association is established, the resolution of symptoms with treatment for neurosyphilis confirms the etiology of the condition.

\section{Conflicts of interest}

The authors declare that there are no conflicts of interest to disclose.

\section{Ethical disclosures}

Protection of human and animal subjects. The authors declare that no experiments were performed on humans or animals for this study.

Confidentiality of data. The authors declare that they have followed the protocols of their work center on the publication of patient data.

Right to privacy and informed consent. The authors have obtained the written informed consent of the patients or subjects mentioned in the article. The corresponding author is in possession of this document.

\section{References}

1. Daniel Diaz J, Sobol EK, Gritz DC. Treatment and management of scleral disorders. Surv Ophthalmol. 2016;61:702-17.

2. Watson PG, Hayreh SS. Scleritis and episcleritis. Br J Ophthalmol. 1976;60:163-91.

3. Doshi RR, Harocopos GJ, Schwab IR, Cunningham ET. The spectrum of postoperative scleral necrosis. Surv Ophthalmol. 2013;58:620-33.

4. Moloney G, Branley M, Kotsiou G, Rhodes D. Syphilis presenting as scleritis in an HIV-positive man undergoing immune reconstitution. Clin Experiment Ophthalmol. 2004;32:526-8.

5. Lee SB, Kim KS, Lee WK, Kim YJ, Kang MW. Ocular syphilis characterised by severe scleritis in a patient infected with HIV. Lancet Infect Dis. 2013;13:994.

6. Barile GR, Flynn TE. Syphilis exposure in patients with uveitis. Ophthalmology. 1997; 104:1605-9.

7. Kim Y, Yu S-Y, Kwak HW. Non-human immunodeficiency virus-related ocular syphilis in a Korean population: clinical manifestations and treatment outcomes. Korean J Ophthalmol KJO. 2016;30:360-8.

8. Fénolland J-R, Bonnel S, Rambaud C, Froussart-Maille F, Rigal-Sastourné J-C. Syphilitic scleritis. Ocul Immunol Inflamm. 2016;24:93-5.

9. Yoon K-C, Im S-K, Seo M-S, Park Y-G. Neurosyphilitic episcleritis. Acta Ophthalmol Scand. 2005;83:265-6.

10. Marra CM, Maxwell CL, Tantalo L, Eaton M, Rompalo AM, Raines C, et al. Normalization of cerebrospinal fluid abnormalities after neurosyphilis therapy: does HIV status matter? Clin Infect Dis. 2004;38:1001-6.

11. Syphilis - 2015 STD Treatment Guidelines. 2019. (Accessed on Jun 17, 2020. Available at: https://www.cdc.gov/std/tg2015/syphilis.htm. 